\title{
The Ritual Paths of Otium and Negotium: An Interpretive Study of Renovatio Imperii in the High Renaissance
}

\author{
NICK TEMPLE \\ Leeds Metropolitan University \\ United Kingdom
}

\section{INTRODUCTION:}

\section{THE POPE AS CORPUS MYSTICUM}

During the Papacy of Julius II (1503-1513) an ambitious programme of Church reform was instigated with particular emphasis on apocalyptic and eschatological notions. This coincided with the inception of a new providential role of Rome. As both repository of memory and catalyst of utopian ideals the city of Rome became the centre of a unique programme of spiritual and physical renovation, instauratio Romae.

Taking the Augustinian concept of the City of God as an inspirational point of departure, the christological hierarchy between civitas sancta and civitas terrena was appropriated by Papal aspirations to reconcile the traditionally divided

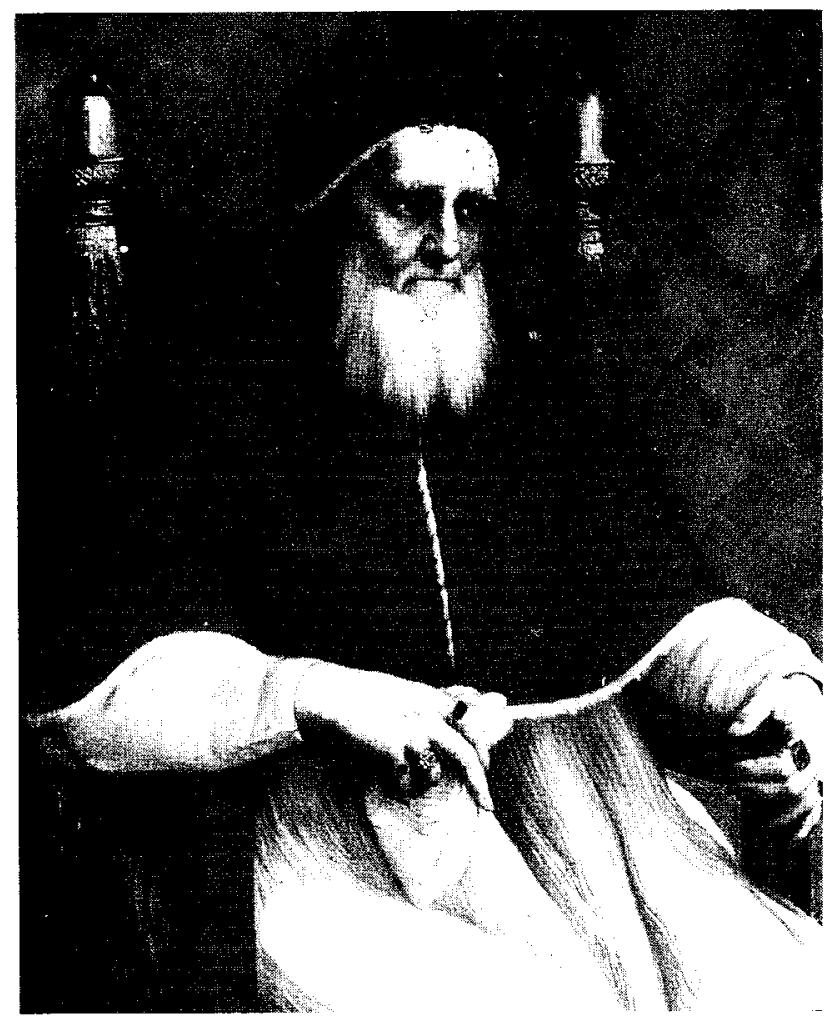

Fig 1. Portrait of Julius // by Raphael functions of sacerdotium and imperium. This was sought through a process of historical re-enactment, or more precisely Renovatio Imperii, in which the personality of the pope played a central role in shaping the future destiny of his city. For Pope Julius II (Fig 1) the creation of a cultural focus in Rome provided an effective catalyst for legitimizing his active political involvement in the affairs of state, through a perceived historical continuity with the imperial past. As the most conspicious feature of Julius' reform programme, the architectural and urban projects of Rome demonstrate a super-human capacity to authenticate a new cultural identity through the re-discovery and re-interpretation of the classical past. This forms the subject of the current investigation.

The complex relationship between papal rule and statecraft is based on the Medieval concept of the Church as polity and the pope as its head, an ideal which is derived from the Pauline doctrine of the 'Mystical Body,' or corpus mysticum. ' In its original christological meaning, the term designated the Sacrament of the Altar. By the end of the 12th c, however, it served as a prototype to the increasing dominance of the body-politic of the Church. By the early Renaissance, the "mystical body" became associated with the head of the hierarchy, the pope himself. This manifests itself architecturally in the form of ritual passage, where the symbolic presence of the pope permeates the urban setting. ${ }^{2}$

The secularization of the Church which first emerged in the late Middle Ages, was paralleled by an equally significant transformation of the affairs of state to one of nearsanctification. Perhaps the most explicit evocation of this inflection between sacred and secular can be found in the politica1/religious system of Dante (Fig 2) ${ }^{3}$ In his Monarchia, Dante attempts to create mutually independent corporate bodies, one 'human imperial', the other 'Christian papal'. Here, he conceived a duplex system of governance, of terrestial and celestial paradises, in which the two offices of imperium and sacerdotium become comparable only when reduced to a state of God (deitas) or man (humanitas). By elevating humanitas to a value in its own right, Dante had overturned the Augustinian celestial/terrestial hierarchy, opening the way to a corporate, rather than religious, body whose membership was determined by exemplary human 


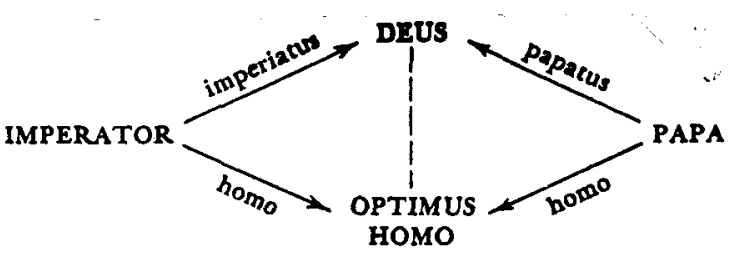

Fig 2. Diagram showing relation between Pope and Emperor based on Dante's Man-Centred Kingship (from Kantorowicz - "The King's Two Bodies.")

qualities rather than adhering to the Christian faith.

Dante's task of creating a juxtaposed, but mutually exclusive, dialectic of Church and State was almost certainly influential on the emerging corpus mysticum of the Renaissance pope. His emphasis on imperium as an embodiment of the kingdom of humanitas became a central theme of the curial humanists. By sublimating man to a level comparable, but not synonymous to the divine, Dante had clearly sought to identify the most elevated conditions that embody humanitas, as a remedy to man's fall from grace. A similar pre-occupation underlay the humanist programme in their search for those exemplary qualities that make an ideal pope.

One can only speculate on the direct influence of Dante's political/religious system on the iconographic programmes of Julius' architectural and urban projects. What is certain is that the Pope and his chief architect/urban planner, Bramante, were avid readers of the great poet, and that Dante himself figures prominently in two of the frescoes in the private library of Julius II, the Stanza della Segnatura. Further investigation of this issue will be made later.

\section{RESPUBLICA CHRISTIANA VS RENOVATIO IMPERII}

The indelible mark of papal presence, celebrated as a form of symbolic transfiguration, is echoed in the mimetic operation of Julius' triumphal entries. In a well-known account of the Pope's entry into Rome on Palm Sunday in 1507, following a military victory in Bologna, Julius II is described as simultaneously re-enacting Christ's entry into Jerusalem and evoking the pageantry of the emperor's triumphal passage into Rome. ${ }^{4}$ As an eschatological event of symbolic renewal and redemption, this 'rite of passage', which was ultimately destined for St Peter's, revealed a particularly bold conception of papal kingship as a parallel and juxtaposed re-incarnation of imperial and christological dramas, which converged on a type of 'caesaro-papism.'

Julius' Pontiff sought to achieve this assimilation of Respublica Christiana with the Roman Empire by focusing on the relationship between Christ and the Augustan age. Caesar was crucial to the Julian identity since the pax romana of Augustus had prepared the way for the reign of Christ ( pax Christi), whose birth in the Augustan Age was presented as divinely pre-ordained. In view of such explicit references to the imperial past, it is not surprising that Rome's significance, as the new earthly dominion of Christendom, was interpreted as predestined in its history, with the Church as the new imperium and the pope as princeps.

The problem of translating this imperial past (Translatio Imperii) into the culture of the 16th c. Papacy, with the many ideological and religious contradictions that it entailed, is especially revealing in the architectural and urban interventions of the ancient city. Before, however, exploring this interplay between political and religious ambitions and their influence on utopian thought, it would be helpful to briefly outline the humanistic understanding of historical consciousness and its influence on artistic developments.

Central to this programme was the conscious revival of classical culture which, for the curial humanists, was sought by following an ideal model, popularly known as Ciceronianism. ${ }^{5}$ By treating the Latin language as an instrument of cultural transmission, the humanists had followed distinct fideistic principles of disseminating knowledge as a means of re-authenticating the political, philosophical and religious realities of their age.

Implicit in this epistemological approach was a twofold process which could be summarized in the following terms: 1. The downward movement of the archaeological or necrophiliac impulse into a forgotten or recondite past.

2. The upward movement of the restorative impulse to bring forth and re-appropriate the corpse to a new harmonious environment.

According to T M Greene, ${ }^{6}$ the former represents the "philological pole" of humanism, conceived as an analytical and rational process, whilst the latter evokes the "creative instinct." When viewed in the context of the ruins of ancient Rome this two-fold process inspired a form of kunst-wollen (or will-to-form), as exemplified particularly in the ambitious urban and architectural projects of Julius' Papacy. These become a central metaphor for evoking the type of fideistic principles that underpin epistemological revelation, mostly notably in perspective and theatre. As instruments of 'faith' these projections into the depths of the urban fabric were also projections into the past, evoking a hermeneutical connection between operations of understanding and interpretation of history. ${ }^{7}$

\section{THE RITUAL PATH:}

\section{A HISTORIOGRAPHICAL RE-ENACTMENT}

In attempting to explore the complex interface between theoretical concepts of Renovatio Imperii and their articulations in the representational iconography of the Julian court a key figure in this regard is the 16 th $\mathrm{c}$ mendicant Giles of Viterbo. ${ }^{8}$ As Prior General of the Order of Augustinian Hermits, scholar and speculative thinker, not to mention favourite preacher of Julius II, Giles presented a mystical vision of Christianity which was based on a particular version of Platonism, mixed with the teachings of Jewish Kabbala.

His juxtaposition of Classical, Jewish and Christological themes created often idiosyncratic and apocalyptic interpre- 
tations of Respublica Christiana. As an enthusiast of Roman history Giles sought to elucidate, in his sermons and writings, a quasi-ancestral link from Old Testament/Archaic Roman civilizations to the Christian age. He hailed Julius II as both Romulus and the new Solomon and referred to Rome as the Holy Latin Jerusalem, with the Vatican hill as Mount Zion and the Tiber as the new River Jordan. ${ }^{9}$

Such interpretations, whilst structured in eulogistic terms, acquire a deeper level of significance when investigated in the context of the urban and architectural transformations of Bramante, specifically his designs for the Cortile del Belvedere and via Guilia/via della Lungara (Fig 3). Both projects intimate the two aspects of imperium and sacerdotium that Julius sought to synthesize. Moreover, they offer a critical framework for re-interpreting utopian thought in the High Renaissance.

In instituting the new Papal palatium as an integral part of the Martyrium complex of St Peters, Bramante's scheme for the Cortile established a dialectical relationship with the ancient city of Rome across the river. By bridging the Papal Palace and Belvedere Villa with a formal avenue of gardens and terraces, Bramante clearly intended to create a visual counterpart to the old imperial capital, thereby echoing (and even rivalling) the imperial seat of his acknowledged predecessor and namesake, Julius Caesar. ${ }^{10}$

By extension, the urban intervention of via Guilia/via

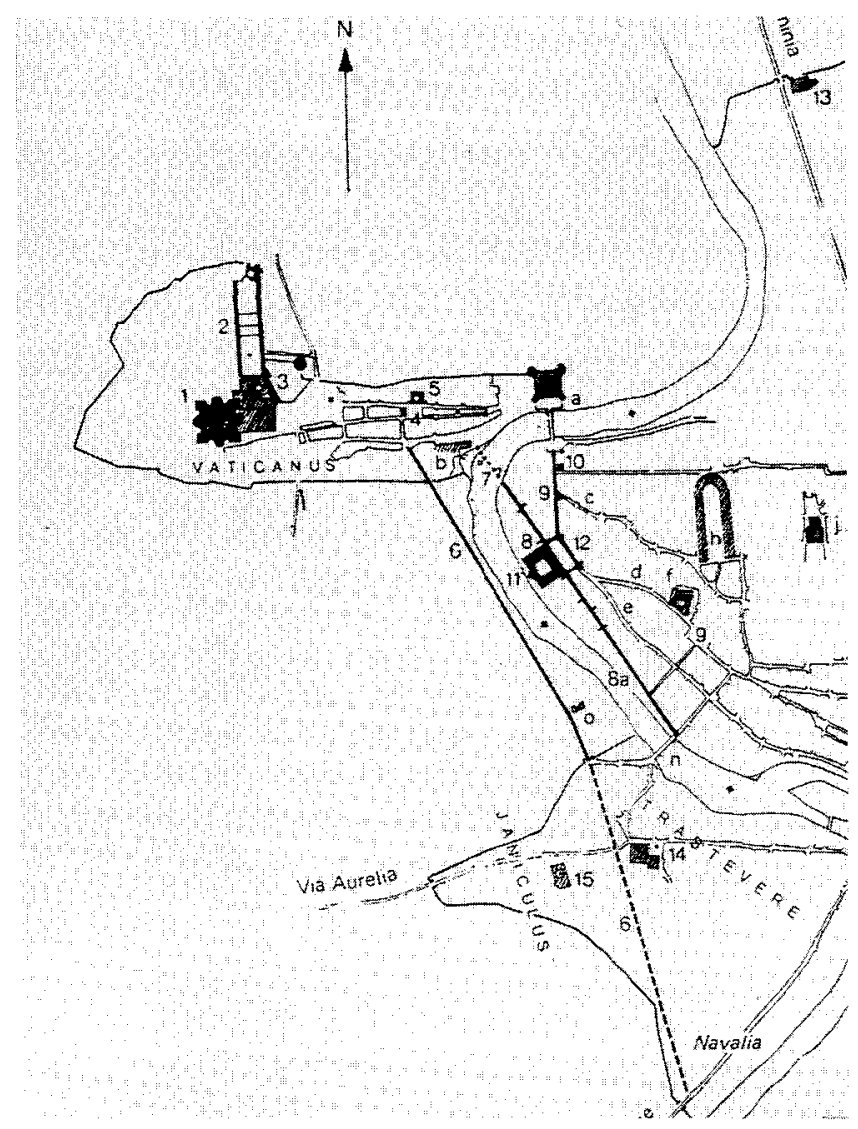

Fig 3. Plan of via Giulia/via della Lungara and Belvedere as reconstructed (from Bruschi)

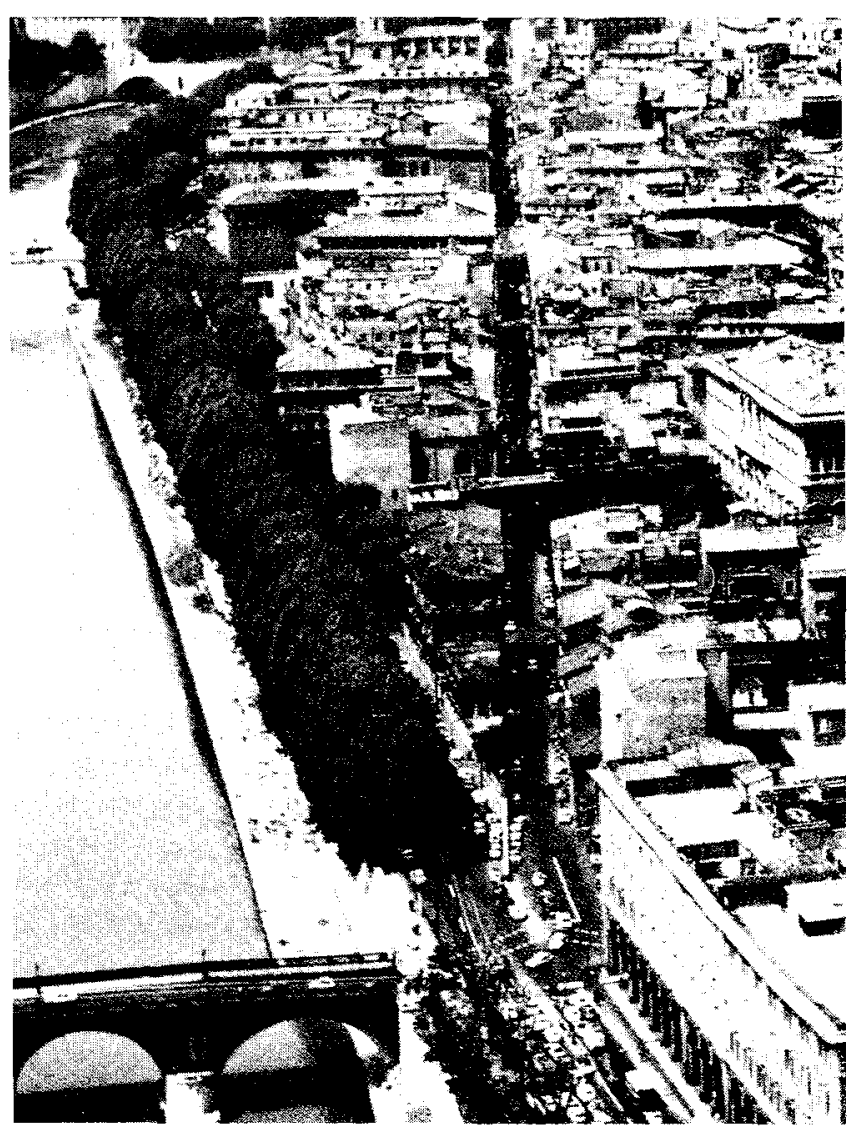

Fig 4. View of via Giulia

della Lungara, flanking the River Tiber, acted as a symbolic threshold between past and present, state and church, sacred and secular etc. In Bramante's original design, these nearparallel vistas seem to evoke an underlying intention to supplant the symbolism of palatium, as summarized in the transient passage of the Cortile del Belvedere, into the urban context of Rome, only here modified as public rather than private 'initiatory' routes circumscribing a sector of the Tiber.

Both streets embody two key aspects of classical life and culture; otium (contemplative life) and negotium (active life), the former articulated as via della Lungara, a villa street and extending from the Vatican to Trastevere and mediating between the Tiber and Gianiculum Hill, and the latter, via Giulia (Fig 4) opposite which originally bounded the secular/ business district of Rome. Furthermore, the dialectical relationship between sanctity/profanity, otium/negotium etc. in this urban intervention, through the ebb and flow of the ancient water course (the new 'River Jordan'), is echoed symbolically in the Cortile of the Vatican Plalace with the insertion, according to James Ackerman, ${ }^{11}$ of a naumachia in the lower piazza (Fig. 5). This marked a critical crossing-point from palace to the elevated paradisical garden of the Belvedere Villa beyond. Here, the relation between the otium of Via della Lungara and the negotium of via Giulia becomes paraphrased as the personal experience of self-renewal of the Pope, passing from Palace to Villa and vice versa. 


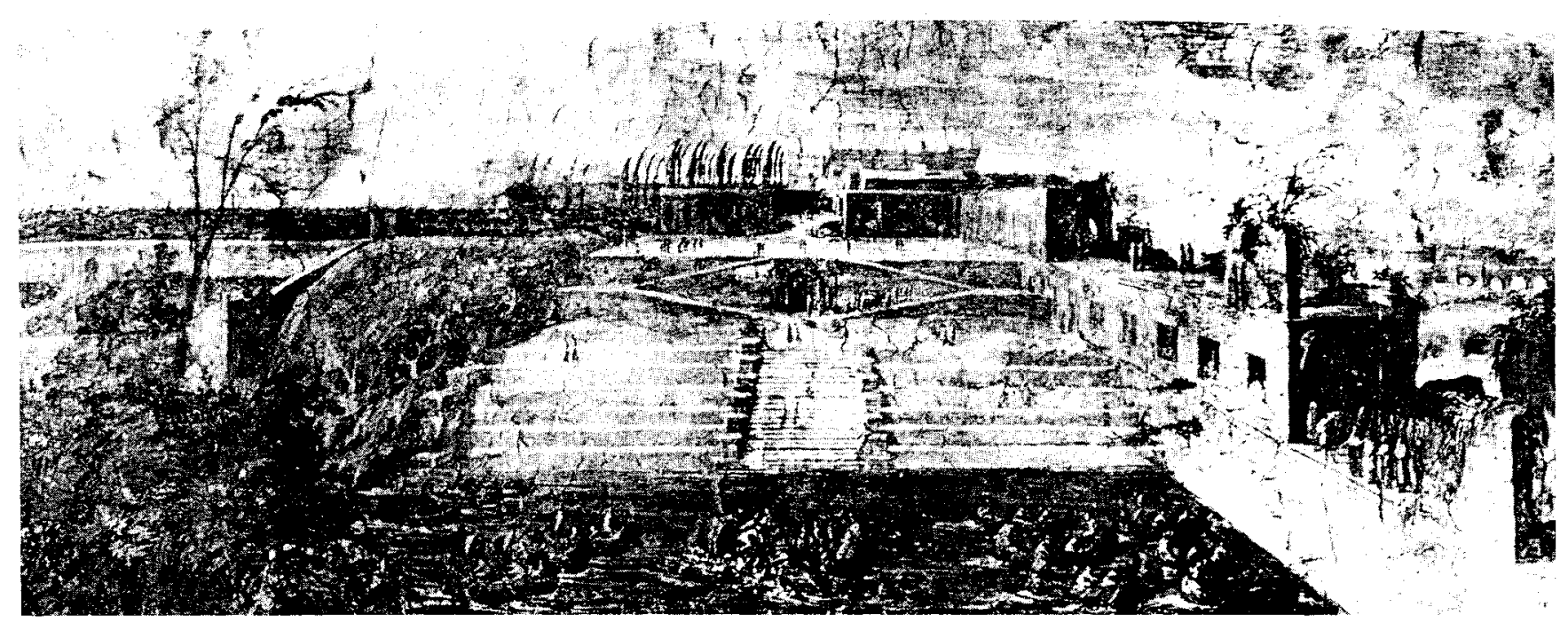

Fig 5. Fresco from Castel Sant'Angelo showing Belvedere with naumachia

By closer examination of Giles ${ }^{12}$ texts, a second but not unconnected meaning to via della Lungara is inferred. Conceived as an important ceremonial and commercial route between the Vatican and the district of Trastevere, the latter under only quasi-papal control during the early 16 th $c$, the location of this street carried a special significance for Giles in the history of Rome, and more essentially in the city's role as inheritor of the Christian faith; "Giles attached great importance to the presence of St Peters on the right of the Etruscan bank of the Tiber, and he related the Christian Saint Peter to the other keybearer, the Etruscan god Janus." ${ }^{13}$

By establishing a theological connection between Peter and Janus, Giles had also articulated an effective symbolic partnership between the Vatican, the resting place of the Christian keybearer, and the Gianiculum, the celebrated site of the mythological origins of Roman religion, as the gift of Janus. Moreover, ancient tradition had connected the tomb of Numa to the Gianiculum. By serving as a pagan model of pontificial authority Numa, the historical founder of Roman religion, became associated with St Peter, the founder of the Roman Church. ${ }^{14}$

What is intimated here is a historiographical connection between the Gianiculum and the Vatican, as the foundation sites of the Archaic and Christian religions of Rome. This ancestral connection is further emphasized in the siting and design of Bramante's paganesque Tempietto, on the Gianiculum itself;

The round Tempietto, with its use of doric columns perhaps drew upon, too, the classical temples dedicated to Hercules, one of which, in the Forum Boarium, had come to light during Sixtus IV's pontificate. Such a design implied the commemoration of Peter as a hero, a kind of Christian Hercules. But Roman circular temples also were associated with the goddess Vesta, whose cult and temple type Numa Pompilius ..... was held to have instituted."15
Thus, besides providing important access to Trastevere from the Vatican, via della Lungara was probably intended to function as a pilgrimage route to St Peters and, it could be argued, to the Gianiculum. In so doing, it defined a symbolic rite-of-passage that mediated between an historic/mythical past and the future destiny of Rome.

\section{PORTA TRIUMPHALIS: RECONFIGURING TEOLOGIA AND FILOSOFIA}

The discussion so far has singled out via della Lungara for detailed investigation as a possible example of Giles' historiographical interpretation of Respublica Christiana. The temptation, however, to consider this iconography as unique risks ignoring the more general thematic relationships between this street and via Guilia opposite, as outlined earlier.

The clear antithesis between the concepts of contemplative and active lives is revealed in the contrasting architectural vocabulary of both streets. Renowned for its once palatial villas and gardens, via della Lungara embodied the characteristics of a formalized arcadian landscape with open views of the meandering river, and semi-rustic landscape of the adjacent Gianiculum. Via Giulia, by contrast, is an enclosed urban street defined by grand palaces, and in close proximity to established banking institutions. Influences can be traced, in its design, in the utopian images of the Urbino Court, and thence in the later theatrical vistas of Peruzzi. ${ }^{16}$ Here, active political life of the city becomes formulated in the familiar tragic and comic scenes of the Renaissance, a reference perhaps to those sublimated human qualities enobled in Dante's concept of humanitas.

Bramante celebrated the grandiloquence of humanitas by incorporating in his design of via Giulia a vast piazza, intended to address an imposing palace of justice, the unexecuted Palazzo dei Tribunali. Allusions to imperial fora, particularly the Forum of Augustus, are clearly evident in Bramante's sketches and highlight the clear intention of 
his patron to re-invest his age with the culture of classical antiquity in order, no doubt, to legitimize the Pope's aspirations as both Pontifex-Maximus and emperor ofChristendom. By shifting the centre of political control from the ancient Campidoglio to the bank of the Tiber, at the threshold to the Vatican City, Julius II had consciously brought state and Church into direct dialogue, mediated by the body-politic of his court and by his corpus mysticum.

Further insight into the symbolic role of this street is revealed in its relationship to the river. Terminated at important crossing points over the Tiber, the route of via Giulia discloses a continuity with the larger urban context. To the south is the Ponte Sisto, earlier constructed by his uncle Sixtus IV as a major access from the densely populated quarter of Campo dei Fiori to Trastevere. The conscious decision to terminate via Giulia at the threshold of this bridge is indicative of Julius II's desire to re-affirm his rightful place in a contrived dynasty (that of the Della Rovere family) in which architecture becomes the principal rhetorical instrument for the celebration of continuity of rulership.

Similar motives are likely to have influenced the intended crossing-point to the north, only here the project remained unexecuted. Not surprisingly, much speculation has focused on this crucial link to the Vatican, particularly in its relationship to the extant ruins of the Neronian Bridge (or Trionfale) nearby. As if anticipating the creation of a papal triumphal crossing, Sixtus IV had constructed the Ospedale di Santo Spirito on the Vatican side of the Tiber strategically located, in proximity to Castel Sant Angelo, to form a papal/imperial gateway to St Peters and the papal palace beyond.

According to one contemporaneous account, ${ }^{17}$ the pons Julius was to have been constructed on the foundations of the antique Neronian bridge, thus intentionally re-instating the original imperial crossing. Further, from late 16 th $c{ }^{18}$ views of Rome the northern end of via Giulia is represented with a triumphal arch located near the reconstructed Neronian bridge. This supports the theory that via Giulia was intended to be used, at least on some occasions, as a triumphal passage for the 'pontefice imperatore'.

By respecting, however, the antique bridge, as the predetermined location for this papal crossing, the orientation of the new bridge with respect to its adjacent river banks would have presented some awkward conjunctions with adjacent buildings. On the south bank, for example, its oblique relationship to via Guilia has prompted Arnaldo Bruschi ${ }^{19}$ to suggest a re-orientating function of the Trionfale, to visually re-align the ceremonial route with the river crossing. To achieve this, however, he further suggests that the design of the archway must have been centralized in plan, perhaps octagonal, and set in a piazza. This would also have facilitated a visual focus for the adjacent via Recta (today via dei Coronari), from Piazza Navona.

More revealing is Bruschi's suggestion that the design of this multi-faceted triumphal arch may have been used as the architectural setting in Raphael's famous School of Athens. (Fig 6) ${ }^{20}$ Whilst such a hypothesis is difficult to substantiate,

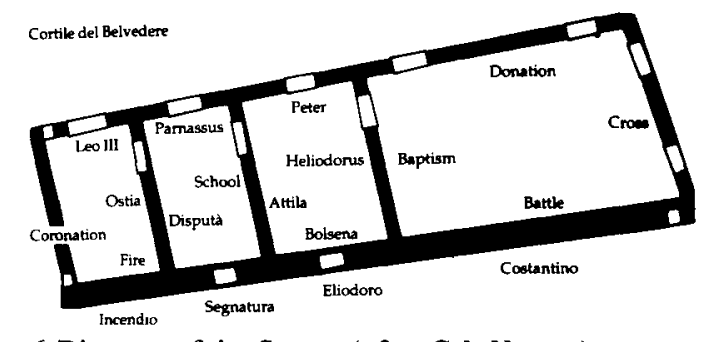

Fig. 6 Diagram of the Stanze (after G L Hersey)

it points to a more general and potentially significant thematic connection, originally posited by Manfredo Tafuri ${ }^{21}$, between the frescoes in the Stanza della Segnatura (Fig 7) and Bramante's urban projects in Rome.

In this thesis Tafuri speculates that Raphael's iconographic programme may represent an ideological "manifesto" of the physical structures envisaged by Julius II for the re-awakened Rome. He succinctly summarizes this relationship as follows:

1. Teologia $($ Disputa $)=$ the New St Peters.

2. Filosophia (School of Athens) $=$ the works of the pontifical palace.

3. Parnaso (Parnassus) $=$ the Belvedere.

4. Iustitia (minor frescoes) $=$ the Palazzo dei Tribunali.

In this investigation, attention will only be focused on the first two hypothetical relationships. Bruschi's theory poses a number of obvious problems, both in respect of the available material and in its symbolic relationship to the other frescoes in the Stanza. A cursory glance at the School of Athens reveals the outline of a conventional triumphal arch in the background, behind the central figures of Plato and Aristotle. If Bruschi's interpretation is taken into account then the function of this motif becomes problematic.

A clearer insight, however, into the symbolism of this fresco, and its relationship to via Giulia, becomes possible when viewed in relation to the Disputa (Fig 8) opposite. In Tafuri's paraphrasing of Bramante's projects in these frescoes there is implied a 'rite of passage' where architecture and painting converge on a journey focused ultimately on St Peter's Basilica (the Disputa). This is carried through visually by the coincidence of the vanishing points of the School of Athens and the Disputa; the distant triumphal arch in the former directly addresses, by virtue of its centrality, the monstrance of the altar (the consecrated host) in the latter. Like the bridge crossings at opposite ends of via Giulia, both points of focus represent only visual terminations to what is a larger ritual experience.

For the School of Athens the path is a physical route defined by the perspectival projection of architectonic forms which open out onto a theatrical setting in the foreground, the scene of assembly of the sages of antiquity. For the Disputa, the journey is articulated as a metaphysical experience, in which the altar becomes less a physical focus and more of a source of numinous emanations, as celebrated in the 'Church Triumphant' above.

Whilst representing two of the cornerstones of scholastic learning, the School of Athens and Disputa reveal an icono- 


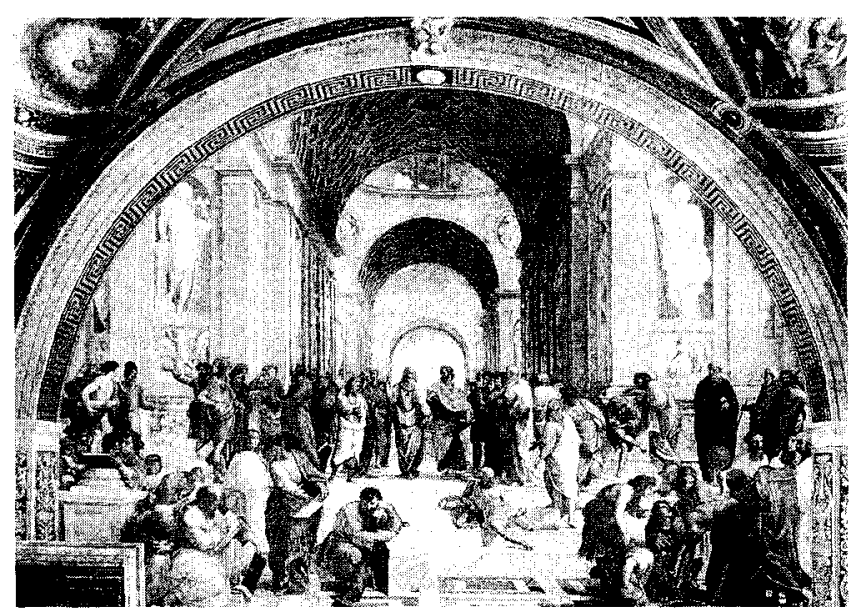

Fig 7. The School of Athens, by Raphael

graphic programme unique to the High Renaissance Papacy. In attempting to formulate the qualities that constitute an ideal pope the curial humanists referred to Plato's concept of the prince as philosopher and its stoical re-interpretations as represented in the emperor/philosopher, Marcus Aurelius. ${ }^{22}$

As embodiment of the body-politic of the Church the pope was thus cast in the image of the emperor/philospher, whose kingship imparts well-being to all of humanitas. It could thus be inferred that this formed a thematic framework to the School of Athens, as an apotheosis of human enquiry and endeavour celebrated in the deliberations of science and philosophy. By evoking a double metaphor of procession, of (1) triumphal passage manifested in the architectural language, and (2) the 'peripateticism' of its two principal personalities, Plato and Aristotle, the iconography of the School of Athens converges on a new type of corpus mysticum adumbrated earlier.

Tafuri's interpretation of this symbolism, as a reference to the alterations of the Papal Palace requires some reappraisal in this context. For the Julian court these alterations tended to focus on the problematic relationship of the Vatican Palace with both the City and the Belvedere Villa; this was manifested predominantly in the Logge di Raffaello

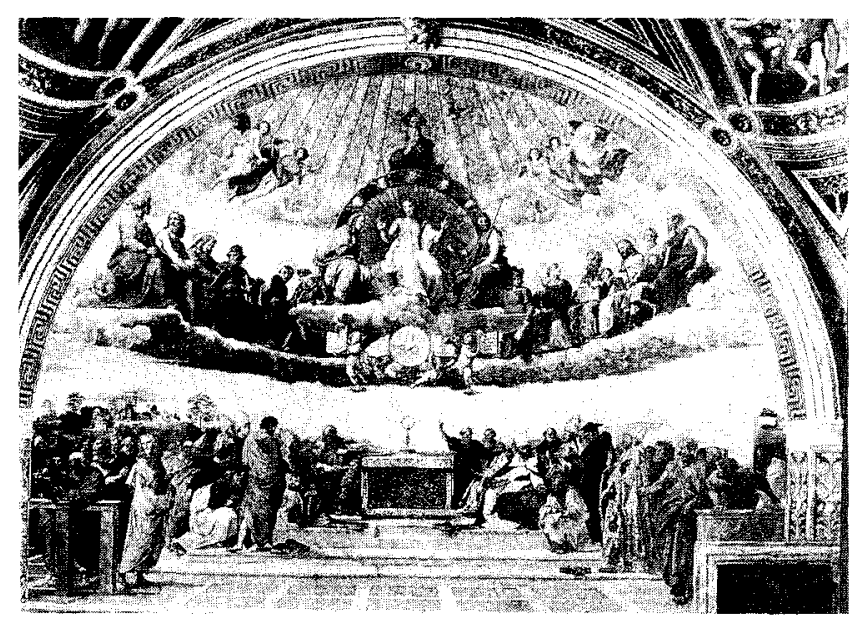

Fig. 8 The Disputa, by Raphael (the new 'Septizodium') and Cortile/Papal Apartments respectively.

As an urban extension to these architectural re-orientations, via Giulia/via della Lungara represent the fulfilment of absolute papal authority on the secular affairs of Rome. The School of Athens thus assumes the role of a 'narrative' of this authority, manifested as a journey of discovery and selfrenewal enacted by the Pope himself, leading ultimately to the new St Peters (the Disputa opposite).

As a potential symbolic marker to the 'New River Jordan', the triumphal arch in the background designates the threshold between the secular and sacred cities (Rome/Vatican), at the bridge crossing (Trionfale). At the same time, this motif highlights a notional transition-point in the humanistic epistemological programme outlined earlier; framing the two great minds of western philosophy, this triumphal passage celebrates the theoretical translation from the "downward movement of archaeology" (the historic past embodied in the ancient city) to the "upward movement of the restorative process" (the future destiny of Rome manifested in the Vatican). This latter creative instinct is projected into the Disputa opposite which represents, on the right, the first granite blocks of the apse of the new St Peter's Basilica.

Could it not therefore be argued that the School of Athens and Disputa confer respectively the humanitas and deitas of Dante's political/religious system, with their explicit and implicit epistemological and apocalyptic references? Only here, the mutual exclusivity of the two parts, so central to Dante's system, is appropriated metaphorically as a linear space/time event, re-enacting the papal/imperial passage from temporality (the ancient city) to eternity (the "new Jerusalem'). This reveals distinct Augustinian eschatological notions of civitas terrena/civitas sancta ordered in a preordained divine plan of human events.

Collectively, these enduring visual testimonies to the Julian enterprise, and their urban/architectural manifestations, resonate with Giles' peculiar vision of theocratic redemption, as embodied in the corpus mysticum of the Pope himself. The development of such complex iconographic programmes in the early 16th c. highlights an underlying awareness of an emerging problem of representation, in a period of cultural change. The reliance on the solemnity of historicized ritual events as mechanisms for re-animating the city is symptomatic of an attempt to establish a paradigm of culture, where representation and participation simultaneously converge as re-enactments of Rome's historical/mythological origins. By substituting this new historical consciousness for the traditional ontological thought of the Middle Ages, the Julian court had ushered in a unique world-view whose full cultural implications are only being felt today.

\section{NOTES}

For an historical account of corpus mysticum see Kantorowicz, Ernst H., The Kings Two Bodies, Princeton University Press (1957), Chapter V. 
2 See Paris de Grassi [Master of Ceremonies] "Le due spedizioni militari di Giulio II", 85-95, for a general description of Julius' Papal ceremonials.

${ }^{3}$ Kantorowicz, op.cit., Chapter VIII.

${ }^{4}$ See Pastor, Ludwig, Storia dei papi, Vol III, Roma (1910) 721 722.

5 For an evaluation of the influence of Ciceronianism on Papal humanism see D'Amico, John F., Renaissance Humanism in Papal Rome, John Hopkins University Press, Baltimore (1983) $115-143$.

' Greene, Thomas M, "Resurrecting Rome: The Double Task of the Humanist Imagination ", 41-54, in Ramsey P.A. (Ed)Rome in the Renaissance: The City and the Myth, New York (1982)

7 I refer here to Paul Ricoeur's investigation of hermeneutical theory, see Ricoeur, Paul, Hermeneutics and the Human Sciences, Cambridge University Press (1984) 43-62.

* See O'Malley, John W, Giles of Viterbo, on Church and Reform.

"O'Malley, John W, "Man's Dignity, God's Love and the Destiny of Rome" in Viator: Medieval and Renaissance Studies (1972), Vol 3, 411-416.

${ }_{10}$ Much has been written on the relation between Julius II and Julius Caesar. For a balanced account see Stringer, Charles L,
The Renaissance in Rome, Indiana University Press (1985), 238-246.

"Ackerman, James, "The Belvedere as a Classical Villa", in Journal of the Warburg and Courtauld Institutes, 14 (1951), 7091.

12 See Pfeiffer, Heinrich, "Le Sententiae ad mentem Platonis" in Roma and L'Antico nell "Arte e nella Cultura del 500, Instituto della Enciclopedia Italiana (1985).

${ }^{13}$ Partner, Peter, Renaissance Rome: 1500-1559, University of California Press, Berkeley (1976) 208-209.

14 Stringer, op.cit., p 189.

is ibid

16 See Bruschi, Arnaldo, Bramante Architetto, Bari (2a ed. 1973) 135-147.

${ }^{17}$ Bruschi, op.cit., p 628.

18 op.cit., p 644 (Note 66).

19 ibid.

20 ibid.

21 Tafuri, Manfredo, "Roma instaurata", p 63, in Raphaello architetto, catalogo mostra Milan (1984).

${ }^{22}$ For an account of the humanistic concepts of the ideal pope see McManamon, John M, "The Ideal Renaissance Pope" in Archivum Historiae Pontificiae 14 (1976), 9-70. 